\title{
New data on geology of the Southern Urals: a concise summary of research after the period of EUROPROBE activity
}

\author{
Victor N. Puchkov \\ Institute of Geology, Ufa Scientific Centre, K. Marx Str. 16/2, Ufa 450077, Russia \\ Correspondence to: Victor N. Puchkov (puchkv@ufaras.ru)
}

Received: 2 April 2016 - Published in Solid Earth Discuss.: 12 May 2016

Revised: 20 July 2016 - Accepted: 25 July 2016 - Published: 31 August 2016

\begin{abstract}
The period of official activity of the EUROPROBE commission was conducted in the Urals with implementation of the URALIDES program, which stimulated many qualified geologists from western research institutes and universities to come to the region and work with local geologists on topical problems of Uralian geology. The author aims to answer questions as to what interesting results have been obtained in the Southern Urals in the last decade, after most foreign researchers left the Urals, and how these results correspond to the scientific conclusions that had been reached before.
\end{abstract}

\section{Introduction}

The decade between 1992 and 2001 was of special importance for the geology of the Urals. It was characterized by a sudden surge of research activity from teams of geologists and European geoscience communities. They came to see the Urals and apply their skills and knowledge for a better understanding of this famous and extraordinarily rich region. Among the main reasons for this "invasion", one may mention the famous "perestroika" and "glasnost", followed by the transition to openness of the USSR society and free access to the Urals that previously had almost been forbidden to foreigners before the 1990s. The first meeting of EUROPROBE in the Urals (May of 1991) took place in the city of Beloyarsk, in full view of its "top secret" nuclear power station, and the excursions (guided by the author) went from the biggest industrial city, Sverdlovsk, in five directions. It was a time of great plans and optimistic hopes for better understanding and co-operation between nations. The geology, knowing no political boundaries, was good grounds for it.
The EUROPROBE program was initiated at the 27th International Geological Congress in Moscow, 1984, as a plan for multidisciplinary research in Europe, including the European part of the USSR and the whole of the Urals. The aim of the program, inherited from the earlier International Lithospheric Program (ILP), was a better understanding of the structure and tectonic evolution of the lithosphere of Europe and the dynamic processes that had controlled its evolution through time. Following and enhancing the ILP plans, EUROPROBE went on with organization of seismic profiles aimed to reveal the deep structure of the most interesting regions. Along with these profiles, great attention was paid to integrated studies of geology, tectonics, geodynamics, geochemistry, petrology and isotopic age of magmatism and metamorphism, paleomagnetic and geothermal studies, basin analysis and some other topics. Among 10 target areas of research, corresponding to 10 projects, in which about 30 countries participated, URALIDES was selected as one of the most attractive. Some more research programs were approved and realized later, just before the end of the 10-year EUROPROBE program or even several years later. The most closely related to URALIDES were the latest TIMPEBAR (Timan-Pechora-Barentsia) and POLAR URALS programs.

During the time of EUROPROBE activity, important financial support was received from the European Science Foundation (ESF), which provided a resource for the work of the Science and Management committees and allowed the running of annual workshops for every project, with some travel money budget. Support was also provided by INTAS (the International Association for Promotion of Co-operation of New Independent States). However, the main support was provided by the participants themselves, organized into individual research groups, often multinational, funded from 
national science foundations and councils of their respective countries.

In the Southern Urals, the main and most expensive task was the URSEIS-95 seismic profile, $>400 \mathrm{~km}$ long, which was an integrated seismic experiment. The work was accomplished by co-operative efforts of an international consortium (Russia, Germany, United States and Spain), with participation of Spetsgeofizika, Bazhenovskaya Expedition, Bashneftegeofizika (Russia), DEKORP GFZ and Karlsruhe University (Germany), INSTOC Cornell University (United States) and ICTJA-CSIC (Barcelona, Spain). A combination of several methods was applied in this study. The common depth point (CDP) combined acquisition by means of vibration, and explosion excitation was accompanied by a wide-angle experiment. All acquisition was performed during one field season of 1995, and the following processing and interpretation took several subsequent years. The results were regularly published in the western and Russian literature. The profile was evaluated as an ambitious and successful project (Berzin et al., 1996; Carbonell et al., 1996; Echtler et al., 1996; Knapp et al., 1996; Morozov, 2001 and others). Along with the geophysical research, significant geological field work was carried out. The most stable and long-lasting co-operation was organized in these years in the Southern Urals between the geologists of the Institute of Geology in Ufa (Ufimian Scientific Centre) and colleagues from the Institute of Earth Sciences Jaume Almera - CSIC, Barcelona; University of Oviedo, Spain; Max Planck Institute for Nuclear Physics, Heidelberg, Germany; Institute of Geosciences and Geography, and the Geiseltalmuseum, Martin Luther University of Halle-Wittenberg, Halle, Germany; Institute of Geology and Palaeontology, RWTH Aachen University, Aachen; Technical University, Berlin; Institute of Mineralogy and Economic Geology, RWTH Aachen University, Aachen, Germany; Institute of Geology, Mineralogy and Geophysics, Ruhr University, Bochum, Germany; and the Geological Survey of Finland. More episodically several other teams worked in the Southern Urals, with a participation of geologists from the Institute of Geology and Geochemistry; Institute of Geophysics (RAS), Ekaterinburg; Geological Institute of Moscow(RAS); Moscow State University; Institute of Mineralogy, Miass. They co-operated with geologists from the universities of Udine, Naples, Modena and Genoa, Italy; Natural History Museum, London; Southampton Oceanography Centre; NERC Isotope Geosciences Laboratory, Keyworth, Nottingham, United Kingdom; Dalhousie University, Canada; BRGM, France; GFZ, Potsdam, Germany; University of Granada and the University of Jaén, Spain; Geological Institute, ETH, Zurich, Switzerland; Uppsala University, Sweden. The teams have published several scientific papers in many leading peerreviewed geological journals. In addition, several special issues of such journals, dedicated to the geology of the Urals, have been published (Pérez-Estaún et al., 1997; Meyer and Kisters, 1999; Brown et al., 2002).
The final events of the main EUROPROBE campaign were publications of two large volumes, partially summarizing the work that had been done (Gee and Stephenson, 2006; Pavlenkova, 2006). Of special interest, concerning the developments in the URALIDES program as a whole, are the contributions of Brown et al., Matte, Kashubin et al., Bosch et al. and Gee et al. in the first of the volumes, and chapter 4 in the second volume (see Puchkov et al., 2006).

The decade of the 1990s was very difficult for Russian geology. Yeltsin's political and economical reforms, realized under seemingly attractive slogans of democracy, market economy, privatization, etc., turned out to be an ill-conceived and badly organized adventure, and led to the destruction of industry (and the Geological Survey as well), the breakoff of business ties, outright banditry, sharp drops of GDP and living standards, low financing and irregular payments of salaries in science and other factors that negatively influenced the level of scientific research in the country. In these conditions, the continued arrival of foreign colleagues who had funding for field research and laboratory analyses permitted the continuation of scientific studies of the geology of the Urals at a relatively decent level and at good progress. Although the USSR geologists belonged to one of the strongest professional communities in the world, providing knowledge of $1 / 6$ of the world land area with its richest deposits, the cooperation with so many representatives of different Englishspeaking scientific schools enriched them with many ideas of modern science, and provided an impetus for a further development.

The aim of this paper is not to describe the achievements of this period, which are well known and easy to find in published English-language literature, and probably deserve a special analysis, but to summarize, at least partially, what interesting research has been done on the geology of the Southern Urals in the last decade (2006-2016).

\section{Stratigraphy}

Although stratigraphy was not the main focus of the URALIDES project, it had important implications for conclusions made in the structural and geodynamic studies of the Urals.

\subsection{Precambrian}

The Precambrian stratigraphy was always a priority with geologists of the Southern Urals because the section of weakly metamorphosed Proterozoic sediments of the Bashkirian Meganticlinorium, $\sim 15 \mathrm{~km}$ thick, was accepted as the stratotype of the Riphean, and is still part of the Russian Stratigraphic Code and General Stratigraphic Scale of Russia (GSSR), which is widely used for geological mapping and prospecting. In the last decade, these studies were supported by more in depth studies of volcanism and isotope age de- 
termination with the application of modern methods, which were almost unavailable in earlier times, except for the valuable data obtained by U. Glasmacher under the URALIDES project.

The Riphean sediments comprise volcanic rocks of several successions, which permitted us to refine the stratigraphic scheme, based first of all on new isotopic ages, obtained with new techniques. Our work was stimulated by the understanding that the International Stratigraphic Scheme (ISS) of division of Meso- and Neoproterozoic into systems/periods of equal duration (200 Ma) contradicts the traditional principles of stratigraphy.

Until recently, the Riphean was subdivided into three systems (periods): the Lower - Burzyanian, Middle - Yurmatinian and Late - Karatavian. We added to it the Uppermost (Terminal) Arshinian system (see below). The isotope ages of the boundaries of these units were updated (Puchkov et al., 2014).

The base of the Riphean section is situated $200-400 \mathrm{~m}$ lower than the volcanics of the Navysh Subformation, at the base of polymictic sandstones of the Ai Formation (Burzyanian series), which overlies the high-metamorphic grade Archean-Paleoproterozoic Taratash crystalline complex with an angular unconformity (Sergeeva et al., 2013). The isotopic study of events in the Taratash Complex dates the last episode of granitization at amphibolite facies conditions in the crystalline basement of this region as $1777 \pm 79 \mathrm{Ma}$ (Krasnobaev et al., 2011) and is also in accordance with data (Sindern et al., 2006; Ronkin et al., 2012) on the minimal age of granites of the complex (1800 Ma). It constrains the lower age limit for the base of the Riphean.

The age of the Navysh Formation at the western limb of the Taratash uplift was determined as $1752 \pm 11 \mathrm{Ma}$ by U-Pb analysis of zircons at SHRIMP II (VSEGEI) (Krasnobaev et al., 2013c).

At the base of the Middle Riphean (Yurmatinian system), the volcanogenic-terrigenous Mashak Formation is situated. Two zircon samples from Mashak rhyolites were analyzed by the U-Pb CA-IDTIMS method at Boise University (United States), and the dates of $1381.1 \pm 0.7$ and $1380.2 \pm 0.5 \mathrm{Ma}$ were obtained (Puchkov, 2009b). It was close to the precise date of the Main Bakal dike, sampled by us and analyzed in the isotope laboratory of Toronto University (Canada): $1385.3 \pm 1.4 \mathrm{Ma}$ (U-Pb method, baddeleyite) (Ernst et al., 2006). The dike cuts the Bakal Formation and is comagmatic to the Mashak basalts. A new series of U-Pb zircon analyses was carried out in VSEGEI (SHRIMP). An average weighted date of rhyolites for four samples was $1383 \pm 3 \mathrm{Ma}$; a presence of rare ancient crystals was also registered (1597 $\pm 27 \mathrm{Ma}$ ) (Krasnobaev et al., 2013a). At the same time, two samples of zircons were sent to SHRIMP in Australia (one new and one for a control). Both gave practically the same results: $1386 \pm 5$ and $1386 \pm 6 \mathrm{Ma}$ (Puchkov et al., 2013). This laboratory has also reported the presence of some older crystals: $1420-1550 \mathrm{Ma}$; they are interpreted as being inherited from a substrate. All the dated samples are situated ca. $300-400 \mathrm{~m}$ above the base of the Yurmatinian series, and therefore we proposed the age of the boundary between the Burzyanian and Yurmatinian series to be ca. $1400 \mathrm{Ma}$.

In the area of the Tirlyan syncline of the Southern Urals, the Paleozoic sediments overlie a thick (up to $1.5 \mathrm{~km}$ ) series of terrigenous deposits unconformably, including tillitelike conglomerates. In the middle of the section there is a considerable unit of volcanogenic and volcano-sedimentary deposits. It overlies an erosional contact with the Uk Formation of the Upper Riphean. Until recently, this series was described as the Arshinian Formation and belonged to the Lower Vendian. We suggested changing the rank of the unit and regarding it as a series (Kozlov et al., 2011a). The study of zircons extracted from the volcanic rocks of Igonino Formation of this series led us to conclude a polychronous character of the Arshinian volcanism, with two main stages of activity at levels of $707.0 \pm 2.3$ and $732.1 \pm 1.7 \mathrm{Ma}$ (Krasnobaev et al., 2012). Taking into account that the accepted age of the base of the Vendian is now at $600 \pm 10 \mathrm{Ma}$ and that of the Vendian/Riphean boundary is not older than 635-650 $\mathrm{Ma}$, we suggest a new unit at the top of the Riphean - as the Terminal, Uppermost Riphean.

These data permitted us to correlate the Riphean scheme with the Meso- and Neoproterozoic units of the ISS and also suggested a correlation with the Chinese scheme (Sinian to Changcheng units) (Fig. 1).

The Uralian section characterizes only the easternmost part of an extensive basin, which occupied a considerable part of the Volgo-Ural oil and gas province (VUP) in the Meso-Neoproterozoic, has a thickness of $0-10 \mathrm{~km}$ and is concealed under a Paleozoic sedimentary cover, $2-3 \mathrm{~km}$ thick. In the province, a couple of dozen deep boreholes penetrated the Proterozoic deposits, and this permitted the construction of the stratigraphic scheme of the VUP part of the basin, having the same fundamental features as of the Southern Urals, though differing in many details. The correlation between the Uralian and VUP stratigraphic schemes serves much as the refinement of the latter. Moreover, it was shown that a stratigraphic section of a unique borehole in the Urals $5 \mathrm{~km}$ deep, 1-Kulgunino (Kozlov et al., 2011b), is transitional and can be described as a combination of the Uralian and platform schemes. As for the oil and gas prospects of the Riphean section, they are still uncertain because the quantity of deep boreholes is insufficient. However, the possibility of discovering new deep deposits cannot be discarded and needs further consideration.

\subsection{Paleozoic}

The most important results in the stratigraphy of the Paleozoic during the last decades were connected with the study of conodonts along with knowledge of some other orthostratigraphic faunas. The results and their impact on the pale- 

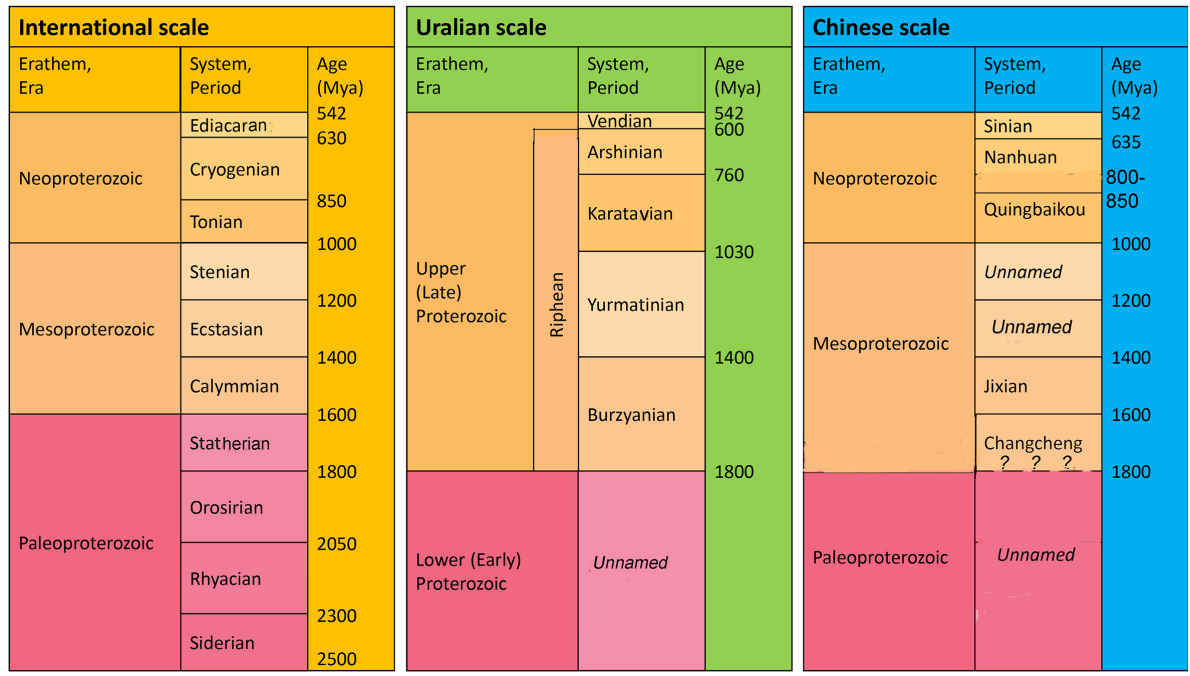

Figure 1. Correlation between the international stratigraphic Scheme of the Proterozoic (Gradstein and Ogg, 2012), the regional stratigraphic scheme of the Upper Proterozoic of the Urals (Uralian scale; Puchkov et al., 2014) and the geological timescale of the Proterozoic in China (Lu et al., 2008; Li et al., 2013).

ogeodynamics were summarized at the end of the twentieth century by Puchkov (2000).

Progress in the stratigraphy of the Ordovician of the territory to the west of the Main Uralian Fault has been marked by the recent publication of Mavrinskaya and Yakupov (2016), based on conodonts and chitinozoans, with carbon isotope analysis, conducted in Syktyvkar isotope laboratory, revealing the global Hirnantian event in the studied sections. Among publications on the stratigraphy of the Ordovician of the Sakmara allochthon, the book of Korinevsky (2013) and Ryazantsev's thesis (2012) must be mentioned. The importance of the latter is that it contains proofs for the existence of the Ordovician Guberlya island arc, first suggested by Zonenshain et al. (1990).

Progress in Silurian stratigraphy, in which well-studied graptolites play the main role, is not so conspicuous, with the exception of some episodic publications, for which conodonts could be used.

Progress in the Devonian conodont-based stratigraphy, mainly in the Magnitogorsk zone, is much more evident and solid, and is summarized in the books of Maslov and Artiyshkova (2010) and Artyushkova (2014), the results of long and intense work. The specific feature of this research was that the conodonts were collected in shale and jaspers among effusives, and work with such material needs a special approach on the field and in the laboratory (see also Puchkov, 2000). The results of the work were demonstrated on the field excursion before the international conference "Biostratigraphy, paleogeography and events in Devonian and Lower Carboniferous" (Artiyshkova et al., 2011)

The most recent results of research on the stratigraphy of Carboniferous and Permian deposits were summarized in the materials of the Carboniferous-Permian Congress in Kazan,
2015. The importance of Carboniferous and Lower Permian sections of the Southern Urals for the development of the International Stratigraphical Scheme was demonstrated in two field excursions: Kulagina et al. (2015) and Chernykh et al. (2015).

Generally speaking (see the above references), the Southern Urals is extraordinarily rich in type sections and candidates for establishment of Global Boundary Stratotype Sections and Points (GSSP), compared to all other regions of Russia (Riphean stratotype and bases of global stages: Serpukhovian, Asselian, Gzhelian, Sakmarian, Artinskian and Kungurian). The Bashkirian stage was also established in the Southern Urals, although its boundaries do not meet the very strict conditions for GSSP establishment. Work on all of them, with international participation, has gone on constantly during the last decade and earlier.

Mesozoic and Cenozoic stratigraphy has progressed slowly in the last decades, with the exception of the youngest strata, where the work of the Laboratory of Cenozoic in the IG USC RAS (Ufa) resulted in updated stratigraphic schemes of the Neogene and Quaternary, which also was favorable for a better understanding of the neo-orogenic stage of the Urals development (Danukalova et al., 2002; Puchkov and Danukalova, 2009 and some latest publications).

\section{General geology, tectonics and geodynamics}

Active work on the geology of the Urals and Cis-Urals was extended in the last decade by V. Puchkov and his colleagues. Personal experience in all tectonic zones and all latitudes of the Urals, obtained during more than half a century of research activity, permitted the author to write a book with 
an analysis of the most important but insufficiently clarified questions of stratigraphy, tectonics, geodynamics and metallogeny, and to provide a general overview of the fold belt, using all the available materials, including those obtained under the EUROPROBE program (Puchkov, 2010). It was, in fact, an extension and enhancement of the previous book (Puchkov, 2000). The material of the recent book is organized according to a structural-historical principle. The book is divided, apart from an introduction and conclusions, into five sections, corresponding to five structural and historical stages, established in the whole territory: ArcheanPaleoproterozoic, a time of formation of the Volgo-Uralia continent and its amalgamation with other blocks into Baltica continent; Riphean-Vendian (Meso- and Neoproterozoic), a stage that was finished with the formation of Timanides; Paleozoic-Early Mesozoic stage, corresponding to the development of the Uralides; the Mid-Jurassic-Miocene platform stage; and the Pliocene-Quaternary neo-orogenic stage. When necessary, the actual questions of stratigraphy are discussed, schemes of structural zonation for every stage are given, problems of structural geology and geodynamics of sedimentary and magmatic complexes are arranged in a chronological order and every chapter is concluded with the characteristics of metallogeny, closely connected with the previous discussion. Ideologically, the book is based on plate and plume tectonics, in their modern versions. All captions for the figures in the book are bilingual; the book is provided with an English summary. It is available at the site of the Institute of Geology, Ufa. In 2011 the book was endowed with the academician A. D. Archangelsky award for outstanding work in regional geology.

The English-language summaries of chapters 3-5 are published as Puchkov (2009b, 2013b), and an updated analysis of the Uralian metallogeny is given in a separate paper (Puchkov, 2016a).

\subsection{Structural research}

Progress has been made in the research of the tectonics of the part of the Uralides concealed under the Mesozoic-Cenozoic cover of the West Siberian plate, based on geophysics and study of boreholes. Data were combined with knowledge of the tectonics of the exposed part of Uralides, and structural correlation was made (Ivanov et al., 2013).

Interpretation of seismic materials aiming at a better understanding of the deep structure of the Urals, that was an important chapter of the URALIDES project, is also ongoing, including a reinterpretation of some parts of the regional URSEIS-95 and ESRU-SB-93-95 profiles. The Candidate of Science thesis of A. Rybalka (2015), who defended it successfully last year, was dedicated to the ESRU-SB-93-95 seismic profile. Being a leading specialist in the Bazhenovskaya expedition for many years, he contributed much to the success of the work on this profile. Not dwelling much upon the results, the author wants to pick out one of the im- portant conclusions of this work that was absent in previous interpretations of the profile. It was a conclusion based on the presence of a reflector below the Urals, gently (under $30^{\circ}$ ) dipping to the west, that is traced through the whole crust and upper mantle to a depth of about $80 \mathrm{~km}$. It is situated just under the modern Ural Mountains and probably played an important role in their formation. In fact, underthrusting of the Transuralian block under the Urals could be the cause of the neo-orogenic movements. In the Southern Urals the presence of such underthrusting is not recorded, but it could be explained by problems in the acquisition and correct interpretation of primary data.

Some additional work has been done for a better understanding of the URSEIS profile as well. As was pointed out by Znamenskii et al. (2013), the pattern of reflectors in the eastern part of the profile, to the east of Kartaly town and the Kartaly (Troitsk) regional fault, a typical flower structure is present, which supports and is evidence for the idea of a wide development of movement along strike-slip faults in this part of the Urals.

In the last years, work on interpretation of seismic profiles crossing the footwall structures of the Main Uralian Fault was continued because new seismic profiles were obtained. Therefore, several new papers on this subject were published, supplying previous interpretations with some more details and ideas (Svetlakova et al., 2007, 2008; Puchkov and Svetlakova, 2012).

\subsection{Plume tectonics}

Very important innovation that appeared in Puchkov (2010, 2013a) and subsequent publications (Puchkov et al., 2013, 2016; Puchkov, 2012, 2013c, 2016b) was a theme of probable plume events in the Urals, a point that was not raised until the early years of the new century. Before and along with these publications, some papers of a general theoretical trend, belonging to the same author, appeared as a contribution to a worldwide discussion: "Do plumes exist?" (Puchkov, 2003, 2009a, 2016b).

Petrogenetic, geochemical studies and isotope age determinations of flood basalts, dolerites, trachybasalts, picrite basalts, rapakivi granites, layered mafic-ultramafic intrusions and also alkaline and carbonatite magmatic complexes of the western zones of the Urals, along with coeval magmatic complexes of adjacent and faraway territories permit the identification of potential large igneous province (LIP) candidates. Their petro-geochemical properties distinguish them from mid-oceanic ridge and subduction types; they are characterized by wide areas of development, very short periods of activity and independence of earlier geological structures in the area (Ernst, 2014).

As mentioned before, in the Southern Urals near the base of the Lower Riphean (Uppermost Paleoproterozoic and Lower Mesoproterozoic), covering the crystalline Taratash Complex dated as Archean and Lower Paleoproterozoic, 
there are volcanic deposits of the Navysh Subformation, represented mostly by trachybasalts. The age of the unit was determined as $1752 \pm 11 \mathrm{Ma}$ (SHRIMP, zircons) (Krasnobaev et al., 2013c). It turns out that volcanic rocks of the age range of 1750-1780 Ma are developed not only in some other places of Baltica, but also in northern Africa, Siberia, Laurentia and North China, belonging to the Nuna supercontinent at that time (Puchkov, 2013c; Youbi et al., 2013). Therefore, they may belong to an LIP.

Higher up the section of the Riphean, at the base of the Middle Riphean (Mid-Mesoproterozoic), rhyolites of the Mashak Formation were dated by SHRIMP and CAIDTIMS U-Pb methods in three isotopic laboratories as 1380-1385 Ma (see above). The same ages have been obtained for rapakivi granites, layered gabbro (Kusa-Kopan Intrusion), carbonatites (Sibirka) and dolerite dykes and sills that widely developed in the Southern Urals and are encountered in boreholes of the East European platform; magmatic rocks of the same age are traced to Greenland, Laurentia and Siberian cratons, and represent the beginning of the Nuna supercontinent breakup (Ernst et al., 2008; Puchkov et al., 2013; Puchkov, 2013c; El Bahat et al., 2013).

Less confidently we may speak of the younger Neoproterozoic magmatic complexes of the Southern Urals as LIPs, dated as ca. $720 \mathrm{Ma}$ (compare with data of Ernst, 2014; Ernst et al., 2016) and $680 \mathrm{Ma}$ - Arshinian and Kiryabinka complexes (Kozlov et al., 2011a; Krasnobaev et al., 2013b), which need further study (Puchkov, 2016a, b).

The study of dolerite dykes and volcanics in the western slope of the Urals has revealed three main Paleozoic volcanic events. The first one, represented by subalkaline volcanics is connected with a rift process that started at ca. $490 \mathrm{Ma}$, the beginning of the Ordovician, that led to oceanic spreading and formation of the Paleouralian Ocean. This accompanied the formation of the Baltica passive margin (Puchkov, 2002) and can be attributed to a plume-connected volcanogenic type (Melankholina, 2011). The comparable and contemporaneous rifting events, accompanied by volcanism, took place in the Lower-Middle Ordovician along the eastern (in modern co-ordinates) margin of the Siberian continent (Bulgakova, 1991). As shown by paleomagnetic data (e.g., Svyazhina et al., 2003; Paverman, 2016), the "upside-down" position of Siberia, and sub-longitudinal strike of the Uralian margin could suggest close, vis-à-vis positions of the margins, and their volcanism may belong to the same superplume episode, occurring above the same superswell.

The second episode was marked by an eruption of trachytes in the Bashkirian Meganticlinorium, and was dated (SHRIMP, zircons) between 435 and 455 Ma. It can be correlated with the early stage of development of the Vishnevogorsk plume-related carbonatite complex (Puchkov, 2010, 2016b; Puchkov et al., 2011; Nedosekova, 2012).

A younger dolerite and basalt complex is Devonian in age and is traced along the western slope of the Urals to PayKhoy and Novaya Zemlya. The rocks match excellently with the Middle-Upper Devonian volcano-intrusive complexes of the East European platform, including flood basalts, dolerite dykes, alkaline and carbonatite intrusions and kimberlites, and belong to the marginal part of the LIP called KolaDnieper (Ernst, 2014; Puchkov et al., 2016). The late, reliably dated stage of the Devonian magmatism of the East $\mathrm{Eu}-$ ropean platform and Urals-Novozemelian belt is Frasnian in age. They are well correlated with the Yakutsk-Vilui plume episode in the Siberian Craton and probably represent a superplume derived from an active part of a single deep mantle LLSVP (Large Low Shear Wave Velocity Province), the socalled Tuzo superswell (Puchkov et al., 2016 and references therein).

Last, but not least, are the Lower Triassic flood basalts, dolerite and rhyolite dikes traced from the easternmost parts of the Southern and Middle Urals to the western margin of the Polar Urals. It has become evident that they belong to the Uralo-Siberian LIP and African superswell (Reichow et al., 2009; Puchkov, 2010).

\subsection{Geology of ophiolites}

Wide development of ophiolites, as association of peridotites, pyroxenites, gabbro, basalts and deep-water sediments (mostly cherty shales and jaspers), is the most characteristic feature of the Urals. Since the International Ophiolite Symposium that took place in Moscow, 1973, and the International Ophiolite Field Excursion (Efimov et al., 1978), the idea of ophiolites as relics of an ancient oceanic crust has become very popular among Uralian geologists and stimulated research activity in this direction. Several international groups of researchers worked in the Urals under the URALIDES program, contributing to the knowledge of the geology of such outstanding objects as, first of all, the Kempirsay, Khabarny, Kraka and Nurali massifs in the Southern Urals and Voykar, Ray-is and Syum-Keu in the Polar Urals.

The summary of the EUROPROBE research, as well as the earlier studies, was given by Savelieva et al. (2006a). It was shown that different massifs belong to different geodynamic situations - mid-oceanic ridges, transition from epicontinental rift to a passive margin or island arcs of different ages. The summary of isotopic age determinations $(\mathrm{K}-\mathrm{Ar}, \mathrm{Sm}-\mathrm{Nd}$, $\mathrm{Rb}-\mathrm{Sr}, \mathrm{Sm}-\mathrm{Nd}$, U-Pb systems), supported by paleontologic determinations of the ages of a sedimentary component of ophiolites, permitted dating of the ophiolites to the limits of the Lower Ordovician-Upper Devonian, admitting that the younger Devonian ages correspond mostly to the secondary processes of deformation and metamorphism. The Precambrian ages were attributed to the ophiolites of Timanides.

However, reliable Precambrian ages, obtained mostly by the $\mathrm{U}-\mathrm{Pb}$ method from zircons, changed this simple picture. Zircons of Vendian age (585, $3 \pm 6 \mathrm{Ma})$ and a couple of zircons dated as $622 \pm 11 \mathrm{Ma}$, plus one grain of $2552 \pm$ $25 \mathrm{Ma}$, were obtained from chromites from a small deposit in dunites of the Voykar Massif (Savelieva et al., 2006b). 
Puchkov $(2006,2010)$ discussed this problem in detail. He indicated that there were more examples of Precambrian isotopic dates ( $\mathrm{U}-\mathrm{Pb}, \mathrm{Sm}-\mathrm{Nd}$, $\mathrm{Re}-\mathrm{Os})$ for ophiolites that were thought to be Paleozoic. The lower, peridotite part of the ophiolite sections, called a "mantle tectonite" by R. Coleman, appears to belong to very ancient, restitic mantle which may preserve relict isotope ratios, corresponding to previous Wilson cycles that are reflected only in the lower parts of the ophiolite sections. For example, ancient zircons were found in the Uralian ophiolites, forming an assembly of differentaged (from 2000 to $200 \mathrm{Ma}$ ) crystals, in dunites, lherzolites and garnet pyroxenites of Kraka massifs (Krasnobaev et al., 2008b).

Broadly speaking, the presence of zircons in peridotites seems to be enigmatic. Deficit of silica in peridotites should not permit the development of zircons - only baddeleyite should form. Therefore, basalt melts were needed to generate zircons - but where are they?

Batanova and Savelieva (2009) gave a review of ideas concerning the transport of basalt melts through the peridotite mantle in spreading zones. The hypothesis of migrating mantle magmas reacting with wall peridotites and the formation of replacive dunites as a result of this process was discussed. It was shown that dike-like dunites, forming nets within harzburgites and lherzolites, were the channels of basalt melts. In this case, zircons and chromites hosting them could be the refractory trace minerals, left by the basalt magma on its way from relatively deep places of partial melting in the mantle to the Earth's surface. The possible deep origin of these minerals is suggested by the presence of diamonds, discovered in chromites in some ophiolite peridotites, including the Ray-Is massif of the Urals (Yang et al., 2014).

The preservation of zircons that spent such a long time within the extreme $P-T$ conditions of the mantle also needs an explanation. Recent (Anfilogov et al., 2015) experimental studies elucidate the interaction between zircon crystals and dunite at $1400-1550{ }^{\circ} \mathrm{C}$. It was shown that at $1400^{\circ} \mathrm{C}$, no interaction of zircon with dunite takes place, and only at higher temperatures does an interaction between zircon and olivine occur, forming an eutectoid mixture of baddeleyite and pyroxene grains. Therefore zircon is very resistant to metamorphic changes, and it explains the coexistence of zircons of different ages, formed under repeating high-temperature processes.

\subsection{Petrology and geochemistry of igneous and sedimentary rocks}

Significant work was done by the group of G. Fershtater on the petrology and geochemistry of intrusive rocks of the eastern slope of the Urals, in collaboration with his colleagues from Granada (Spain) before and during EUROPROBE activities. The results were summed up recently in his monograph (Fershtater, 2013). More local, but very detailed stud- ies of the geology, petrochemistry and chromite ore potential of peridotite Kraka, Talovsky, Mindyak and many other gabbro-peridotite massifs were described in the book of Saveliev et al. (2008). The petrology and geochemistry of intrusive rocks, volcanics and sedimentary successions, hosting them in the Bashkirian Meganticlinorium were summed up recently in the book of Kovalev et al. (2013). Simultaneously, a special book concerning the characteristics of the stratigraphy of the Mashak Formation in the stratotype and petrology of its volcanics was published by Ardislamov et al. (2013). The geology and petro-geochemistry of carbonaceous sediments of the Southern Urals were characterized in the monograph of Snachev et al. (2012).

Devonian and Carboniferous volcanic rocks of the Magnitogorsk zone, the variable geodynamic conditions of their origin and their position in the relic island arc of Paleozoic time were described in two comprehensive papers by Kosarev et al. (2005, 2006).

\subsection{Metamorphism: new data on the geology of HP-LT complexes}

The classic high-pressure-low-temperature (HP-LT) metamorphic Maksyutovo complex has attracted the attention of Russian petrologists at least since the 1950s, and it was very popular with the participants of the URALIDES project. More than a dozen papers were published, dedicated to different aspects of the geology, geochemistry and petrology of this outstanding eclogite-glaucophane complex. The general opinion, summed up and discussed by Puchkov (2010), is that this complex was formed in a process of Paleozoic subduction of oceanic crust and subsequent collision of an island arc and continental passive margin. As a consequence of the buoyancy of the subducted continental margin, the metamorphic complexes were uplifted from the depth of $50-70 \mathrm{~km}$ and exhumed to the earth's surface. Most of the isotopic age determinations, made by different methods, correspond to the Devonian time, and the beginning of exhumation is dated as ca. $375 \mathrm{Ma}$, supported by the information that glaucophane clastic grains appear in the Famennian Zilair flysch formation.

More recently, additional work has been done to obtain more detailed information on the types of eclogites (e.g., Alekseev et al., 2006).

Later on, it was established (Kovalev et al., 2015) that protoliths of different varieties of high-pressure eclogites (high-Ti, moderate-Ti and low-Ti eclogites, graphite eclogites and eclogites of a layered body) were mafic magmatic rocks of different affinity and were Paleozoic in age. The petro-geochemical study has shown that the eclogites are close to basalts that formed in different geodynamic settings - oceanic and subductional, and now they are juxtaposed. Thermodynamic calculations of mineral assemblages of eclogites showed that low-Ti eclogites $\left(680-700^{\circ} \mathrm{C}\right.$, $24 \mathrm{kbar})$, graphite eclogites $\left(660-710^{\circ} \mathrm{C}, 17-18.8 \mathrm{kbar}\right)$ and 
eclogites of the layered body $\left(610-730^{\circ} \mathrm{C}, 16-18 \mathrm{kbar} ; 410\right.$ $430^{\circ} \mathrm{C}, 12.5-13 \mathrm{kbar}$ ) formed at similar temperatures, but at a large scatter in pressure. It was concluded that the pressure variations were caused by the tectonic juxtaposition of bodies during exhumation of the eclogites formed at different depths of the subducted slab.

On the other hand, there was an alternative point of view (Dobretsov et al., 1996) that the protolith of the rocks is Precambrian and experienced ultrahigh-pressure (UHP) metamorphism (550-600 Ma); the final stage of the high-pressure metamorphism (320-385 Ma) occurred simultaneously with the metamorphic transformations of the ophiolites.

Meanwhile, new data have been presented on the conditions of origin and age of the Maksyutovo metamorphic complex. The studies of zircons from garnet-glaucophane schists of the complex (Novotashlinskii area) (Krasnobaev et al., 2015) show that their substrate was constituted of magmatic gabbroids of Neoproterozoic age $(670 \mathrm{Ma})$. The long-term evolution of zircons encompassed the interval from the Neoproterozoic until the Carboniferous (673.1 $\pm 5.4,592.6 \pm 9.4$, $517.0 \pm 7.4,444.9 \pm 4.7$, and $323.0 \pm 8.8 \mathrm{Ma}$ ) - i.e, from the Terminal Riphean till the Visean.

The study of Valizer et al. $(2015,2011)$ was concentrated on UHP jadeite-bearing eclogites, developed near the village of Karayanovo, and on spatially associated ultramafites also considered to have formed under eclogite-facies conditions. A comparison shows that the studied eclogite and ultramafic rocks followed a common $P-T-t$ path. For the jadeite-bearing eclogites, two phases of eclogitization were recognized based on mineralogical data, petrographic observations and isotope geochronology. The first UHP metamorphic stage ( $533 \pm 4.6 \mathrm{Ma}, P>4.4 \mathrm{GPa}, T>$ $700^{\circ} \mathrm{C}$ ) was defined by the assemblage jadeite + grossularalmandine + rutile \pm phengite. This assemblage was later transformed into omphacite + grossular-almandine + phengite + albite + clinozoisite + titanite at a retrograde phase of stage I $(392-485 \pm 2-4$ Ma, $P>3.1-3.4 \mathrm{GPa}, T>$ $633-740{ }^{\circ} \mathrm{C}$ ) with decreasing pressure and temperature. The second prograde phase $(360 \pm 5 \mathrm{Ma}, P>1.1-2.2 \mathrm{GPa}$, $T>450-550^{\circ} \mathrm{C}$ ) of HP metamorphism was marked by the development of a chlorite rim (almandine-grossularpyrope-almandine-grossular, diopside, clinozoisite) around the eclogite body. The ultramafites are represented by olivine-enstatite and enstatite rocks. The thermodynamic parameters of formation of the paragenesis are estimated as $800-1240^{\circ} \mathrm{C}$ and $30-45$ kbar. Geochronological data limits recorded in the zircons cover an interval of more than 2 billion years, between $2350 \pm 53 \mathrm{Ma}$ and the Early Permian $(284.9 \pm 7.3 \mathrm{Ma})$; see above. In general, Paleoproterozoic ages characterize the primary basis of the protoliths, while the Permian zircons record the final transformations of previous generations and the formation of new generations. The intermediate age level $(545.3 \pm 5.5$ and $365.3 \pm 4.2 \mathrm{Ma})$ divides the initial stages of formation-transformation of the substrate and the final stage of its metamorphism, caused by shear deformations. It is probable that this age boundary can be considered as an indicator of the UHP metamorphism.

These new data show that the problem of the history of the Maksyutovo complex is probably more complicated than was thought before.

Beloretsk HP-LT metamorphic complex (MCB) with eclogites within its core attracted attention of German geologists from several universities and institutes, working together with a Russian team from the Institute of Geology, Ufa. The main results were presented in the paper of Glasmacher et al. (2001). The complex is situated in the eastern part of the Bashkirian Meganticlinorium, and it contrasts with the wider western part of this structure, where metamorphism varies between diagenesis and the lower stage of the greenschist facies. Three pre-Ordovician deformation phases were identified in the MCB. The first SE-vergent, isoclinal folding phase (D1) is younger than the intrusion of mafic dykes $(\mathrm{Pb}-\mathrm{Pb}$ single zircon: $1350 \mathrm{Ma})$ and older than the eclogite-facies metamorphism. It is thought that high $P /$ low $T$ eclogite-facies metamorphism is bracketed by D1 and the intrusion of the Akhmerovo granite $(\mathrm{Pb}-\mathrm{Pb}$ single zircon: $970 \mathrm{Ma}$ ). An extensional, sinistral, top-down-to-NWdirected shearing (D2) is correlated with the first exhumation of the MCB. E-vergent folding and thrusting (D3) occurred at retrograde greenschist-facies metamorphic conditions. The tremolite ${ }^{40} \mathrm{Ar} /{ }^{39} \mathrm{Ar}$ cooling age $(718 \pm 5 \mathrm{Ma})$ of amphibolitic eclogite and muscovite ${ }^{40} \mathrm{Ar} /{ }^{39} \mathrm{Ar}$ cooling ages (about $550 \mathrm{Ma}$ ) of mica schists indicate that a maximum temperature of $500 \pm 50^{\circ} \mathrm{C}$ was not reached during the Neoproterozoic orogeny. The scheme of development of the MCB implies that it is different from the development of the western part of the Meganticlinorium, and therefore the MCB is supposed to be a terrane emplaced along a regional strike-slip fault.

The study of the Beloretsk complex continued after that. Krasnobaev et al. (2008a) reconsidered the age of the Akhmerovo granite intrusion; it was shown that the age of the intrusion is $1381 \pm 23 \mathrm{Ma}$; it corresponds to the Mashak level. The $\mathrm{Pb}-\mathrm{Pb}$ single zircon $970 \mathrm{Ma}$ age probably has no geological sense, and therefore the idea that the MCB as an exotic terrane is emplaced along a strike-slip fault does not have enough grounds.

A post-graduate student of the Institute of Geology, A. Galieva, was invited to Aachen by W. Bauer, and this permitted her to make a series of microprobe and ICP Ms analyses. This opportunity helped her to write and defend a Candidate of Science dissertation on geology, petrology and conditions of origin of the eclogites of the Beloretsk complex (Galieva, 2004). It was shown that the protolith of the eclogites was a series of sills. The host rocks of the eclogites are metamorphosed into the same facies. After that, all the rocks experienced a retrograde metamorphism.

The materials of A. Galieva were published in the book of Alexeiev et al. (2006) where an overview of metamorphic processes of the western slope of the Southern Urals 
was presented. Soon after that, another book of this author and his colleagues was published (Alexeiev et al., 2009), dealing especially with the general features of the MCB. In both books it was shown that the complex has a dome-like structure and that the metamorphism is zonal, Barrowiantype, with isogrades of omphacite, garnet, biotite and chloritoid, and with semi-concentric outlines in the western (exposed) part of the dome (the eastern part is concealed under weakly metamorphosed Paleozoic sediments). The eclogitic part of the complex, described by Alexeiev as a specific zoisite-omphacite facies, is different from the usual eclogiteglaucophane-schist metamorphism, and has a transitional nature between it and the amphibolite (kyanite-sillimanite) facies.

PT conditions of origin of the MCB complex were established and evolution of rocks formation reconstructed: from prograde metamorphism $\left(650^{\circ} \mathrm{C}, 13 \mathrm{Kbar}\right)$ to retrograde $\left(500^{\circ} \mathrm{C}\right.$ and $\left.5-5.5 \mathrm{Kbar}\right)$. The further progress of the study was presented in the paper of Kovalev and Timofeeva (2015). They have shown a clockwise $P-T-t$ path of the metamorphism and suggested a geodynamic model of the complex, which included two stages, the first of which corresponded to riftogenic conditions at the time of 730-710 Ma (may be plume-induced) and the second - the main stage which took place during the orogeny of Timanides, when the rocks experienced stress (or stress and lithostatic pressure). Therefore, the MCB was attributed to a collisional type.

\section{Conclusions}

Not all the problems that were being solved during EUROPROBE and after the end of the URALIDES program have been touched upon. For example, we did not discuss a lot of work done during these years under other international programs, especially those dedicated to the mineral deposits of the Urals (MinUrals, GEODE, CERCAMS and others). Resources were not the priority of the URALIDES. The cooperation of the Uralian geologists with the specialists from western countries was always fruitful and stimulating, and served as general progress of earth sciences. There is hope that this paper will have been interesting, especially to many people who participated in the URALIDES project and might wonder what happened after they left the Urals.

Acknowledgements. I wish to express, on behalf of all my colleagues, a deep gratitude to all those who worked with us in the field, exposing ourselves to changing and not always friendly weather, participating in long and exhausting trips, sharing a buckwheat porridge and ideas and helping to process and analyze samples. I want to pay a special tribute to the memory of Andres PérezEstaún, an outstanding scientist and a good friend.

In the last stages of the preparation of this paper, the work was supported by the Russian Scientific Foundation, project no. 16-1710192.
I want also to express my gratitude to the reviewers, Chris Juhlin and Richard Ernst, executive editor, Antonio Jordán, for their useful comments and recommendations and Fernando Bastida for final editing.

Edited by: F. Bastida

Reviewed by: R. Ernst and C. Juhlin

\section{References}

Alexeiev, A. A., Alexeieva, G. V., Galieva, A. R., and Kovalev, S. G.: Metamorphic Geology of the Western slope of the Southern Urals, edited by: Puchkov, V., Ufa, Gilem, 212 pp., 2006 (in Russian).

Alexeiev, A. A., Kovalev S. G., and Timofeeva, A. A.: Beloretsk metamorphic complex, edited by: Puchkov, V. N., Ufa, Gilem, 175 pp., 2009 (in Russian).

Anfilogov, V. N., Krasnobaev, A. A., Ryzhkov, V. M., Kabanova, L. Ya., Valizer P. M., and Blinov, I. A.: Stability of Zircon in Dunite at $1400-1550{ }^{\circ} \mathrm{C}$, Doklady Earth Sci., 464, 963-967, 2015.

Ardislamov, F. R., Saveliev, D. E., Snachev, A. V., and Puchkov, V. N.: The geology of the Mashak Formation of the Yamantau anticlinorium (Southern Urals), Ufa, DesignPress, 216 pp., 2013 (in Russian).

Artiyshkova O. V.: Devonian conodonts from the volcanogeniccherty deposits of the Magnitogorsk megazone of the Southern Urals, Ufa, DizainPress, 152 pp., 2014 (in Russian).

Artiyshkova, O. V., Maslov, V. A., Pazukhin, V. N., Kulagina, E. I., Tagarieva, R. Ch., Mizens, L. I., and Mizens, A. G.: Devonian and Lower Carboniferous type sections of the Western South Urals, Pre-conference field excursion guidebook, Ufa, Sterlitamak, Russia, 20-25 July 2011, 91 pp., 2011.

Batanova V. G. and Savelieva G. N.: Melt migration in the mantle beneath spreading zones and formation of replacive dunites: A review, Russian Geology and Geophysics, 50, 992-1012, 2009.

Berzin, R., Oncken, O., Knapp, J. H., Pérez-Estaún, A., Hismatulin, T., Yunusov, N., and Lipilin, A.: Orogenic evolution of the Ural Mountains: Results from an integrated seismic experiment, Science, 274, 220-221, 1996.

Brown, D., Juhlin, C., and Puchkov, V. (Eds.): Mountain Building in the Uralides: Pangea to Present, American Geophysical Union, Geophysical Monograph, 132, 286 pp., 2002.

Bulgakova, M. D.: The Early Paleozoic of the Northeast of the USSR (sedimentological analysis), Yakutsk, 102 pp., 1991 (in Russian).

Carbonell, R., Perez-Estaún, A., Gallart, J., Diaz, J., Kashubin, S., Mechie, J., Stadtlander, R., Schulze, A., Knapp, J. H., and Morozov, A.: A crustal root beneath the Urals: Wide-angle seismic evidence, Science, 274, 222-224, 1996.

Chernykh, V. V., Chuvashov, B. I., Davydov, V. I., Henderson, C. M., Shen, S., Schmitz, M. D., Sungatullina, G. M., Sungatullin, R. Kh., Barrick, J. E., and Shilovsky, O. P.: Southern Urals, Deep water successions of the Carboniferous and Permian, A Field Guidebook of XVIII International Congress on Carboniferous and Permian, Kazan, Academy of Sciences of the Republic of Tatarstan Press, 88 pp., 2015.

Danukalova, G. A., Yakovlev, A. G., Puchkov, V. N., Danukalov, N. K., Agadzhanyan, A. K., van Kolfschoten, Tp., Eremeev, A. A., 
and Osipova, E. M.: Excursion Guide of the INQUA SEQS-2002 Conference, 30 June-7 July 2002, Ufa, Russia, Dauria Press, 139 pp., 2002.

Dobretsov, N. L., Shatsky, V. S., Coleman, R. G., Lennykh, V. I., Valizer, P. M., Liou, J., Zhang, R., and Beane, R. J.: Tectonic Setting and Petrology of Ultrahigh-Pressure Metamorphic Rocks in the Maksyutov Complex, Ural Mountains, Russia, Int. Geol. Rev., 38, 136-160, 1996.

Echtler, H. P., Stiller, M., Steinhoff, F., Krawczyk, C. M., Suleimanov, A., Spiridonov, V., Knapp, J. H., Menshikov, Y., Alvarez-Marron, J., and Yunusov, N.: Preserved collisional crustal architecture of the Southern Urals - Vibroseis CMPprofiling, Science, 274, 224-226, 1996.

El Bahat, A., Ikenne, M., Søderlund, U., Cousens, B.,Youbi, N., Ernst, R., Soulaimani, A., El Janati, M. and Hafid, A.: U-Pb baddeleyite ages and geochemistry of dolerite dykes in the Bas Drâa Inlier of the Anti-Atlas of Morocco: Newly identified $1380 \mathrm{Ma}$ event in the West African Craton, Lithos, 174, 85-98, 2013.

Ernst, R. E.: Large Igneous Provinces, Cambridge University Press, London, 653 pp., 2014.

Ernst, R. E., Pease, V., Puchkov, V. N., Kozlov, V. I., Sergeeva, N. D., and Hamilton, M.: Geochemical characterization of Precambrian magmatic suites of the southeastern margin of the East European craton, southern Urals, Russia, Geologichesky Sbornik (Geological Proceedings), 5. Ufimian Institute of Geology, Ufa, 119-161, 2006

Ernst, R. E., Wingate, M. T. D., Buchan, K. L., and Li, Z. X.: Global record of 1600-700 Ma Large Igneous Provinces (LIPs): implications for the reconstruction of the proposed Nuna (Columbia) and Rodinia supercontinents, Precambrian Res., 160, 159-178, 2008.

Ernst, R. E., Hamilton, M. A., Söderlund, U., Hanes, J. A., Gladkochub, D. P., Okrugin, A. V., Kolotilina, T., Mekhonoshin, A. S., Bleeker, W., LeCheminant, A. N., Buchan, K. L., Chamberlain, K. R., and Didenko, A. N.: Long-lived connection between southern Siberia and northern Laurentia in the Proterozoic, Nat. Geosci., 9, 464-469, 2016

Fershtater, G. B.: Paleozoic Intrusive Magmatism of the Middle and South Urals. Uralian Branch, Russian Academy of Sciences, Ekaterinburg, 368 pp., 2013 (in Russian).

Galieva, A. R.: Geology, petrology and conditions of origin of eclogites and host rocks of the Beloretsk metamorphic complex (Southern Urals), Dissertation of Candidate of Science (geology, 25.00.01, 25.00.04 Syktyvkar, 144 pp., 2004.

Gee, D. G. and Stephenson, R. A. (Eds.): European Lithosphere Geodynamics, Geo. Soc. Mem., 32, 662 pp., 2006.

Glasmacher, U. A., Bauer, W., Giese, U., Reynolds, P., Kober, B.,Puchkov, V., Stroink, L., Alekseyev, A., and Willner, A. P.: The metamorphic complex of Beloretzk, SW Urals, Russia a terrane with a polyphase Meso- to Neoproterozoic thermodynamic evolution, Precambrian Res., 110, 185-213, 2001.

Gradstein, F. M. and Ogg, J. G.: The Chronostratigraphic Scale, The Geologic Time Scale, edited by: Gradstein, F. M., Ogg, J. G., Schmitz, M. D., Ogg, G. M., Elsevier, Amsterdam, 31-42, doi:10.1016/B978-0-444-59425-9.00002-0, 2012.

Efimov, A. A., Savelieva, G. N., Yazeva, R. G., Saveliev, A. A., Lennykh, V. I., and Puchkov, V. N.: The Guidebook of an excursion "Ophiolites of the Polar Urals", Moscow, GIN AS USSR, 62 pp., 1978.
Ivanov, K. S., Puchkov, V. N., Fyodorov, Yu. N., Erokhin, Yu. V., and Pogromskaya O. E.: Tectonics of the Urals and adjacent part of the West-Siberian platform basement: main features of geology and development, J. Asian Earth Sci., 72, 12-25, 2013.

Knapp, J. H., Steer, D. N., Brown, L. D., Berzin, R., Suleimanov, A., Stiller, M., Lüschen, E., Brown, D., Bulgakov, R., and Rybalka, A. V.: A lithosphere-scale image of the Southern Urals from explosion-source seismic reflection profiling in URSEIS'95, Science, 274, 226-228, 1996.

Korinevsky, V. G.: Geological structure and stratigraphy of Lower Ordovician volcanogenic complexes of the Southern Urals. Ekaterinburg, Uralian Branch of RAS, 72 pp., 2013 (in Russian).

Kosarev, A. M., Puchkov, V. N., and Seravkin, I. B.: Petrologogeochemical features of the Early Devonian-Eifelian island-arc volcanics of the Magnitogorsk zone in the geodynamic context, Lithosphere, 4, 22-41, 2005 (in Russian).

Kosarev, A. M., Puchkov, V. N., and Seravkin, I. B.: Petrologogeochemical features of the Middle Devonian - Early Carboniferous island-arc and collisional volcanics of the Magnitogorsk zone in the geodynamic context, Lithosphere, 1, 3-21, 2006 (in Russian).

Kovalev, S. G. and Timofeeva, E. A.: Thermodynamic conditions of formation and geodynamic reconstructions for eclogites of the Beloretsk complex (Southern Urals), Vestnik IG Komi SC UB RAS, 9, 3-10, 2015 (in Russian).

Kovalev, S. G., Vysotsky, I. V., Puchkov, V. N., Maslov, A. V., and Gareev, E. Z.: Geochemical specialization of structure-material complexes of the Bashkirian meganticlinorium, Ufa, 135 pp., 2013 (in Russian).

Kovalev, S. G., Timofeeva, E. A., and Pindyurina, E. O.: Geochemistry of the Eclogites of the Maksyutov Complex, South Urals, and Genetic Nature of Their Protoliths, Geochem. Int., 53, 285311, 2015.

Kozlov, V. I., Puchkov, V. N., Krasnobaev, A. A., and Sergeeva, N. D.: Arshinian - A New Straton of the Riphean in the Stratotypical Sections of the Southern Urals, Geologicheski Sbornik (Geological Proceedings), Institute of Geology, Ufimian Sci, Centre RAS, 3-8, 2011a (in Russian).

Kozlov, V. I., Puchkov, V. N., and Sergeeva, N. D.: New subdivision scheme of the section of 1-Kulgunino borehole (Southern Urals), Ufa, IG USC RAS, 59 pp., 2011 b (in Russian).

Krasnobaev, A. A., Kozlov, V. I., Puchkov, V. N., Rodionov, N. V., Nekhorosheva, A. G., and Kiseeva, K. N.: The Akhmerovo Granite Massif: A Proxy of Mesoproterozoic Intrusive Magmatism in the Southern Urals, Doklady Earth Sciences, 418, 103-108, 2008 a.

Krasnobaev, A. A., Rusin, A. A., Rusin, A. I., and Busharina S. V.: Zircons of lherzolite-garnet pyroxenite-dunite complex of the Uzyan Kraka (S. Urals), Structural-material complexes and geodynamic problems of Precambrian in Phanerozoic orogens, Ekaterinburg, 58-61, 2008b (in Russian).

Krasnobaev, A. A., Kozlov, V. I., Puchkov, V. N., Busharina, S. V., Berezhnaya, N. G., and Nekhorosheva, A. G.: Zirconology of Iron Quartzites of the Taratash Complex (Southern Urals), Dokl. Earth Sciences, 437, 527-531, 2011 (in Russian).

Krasnobaev, A. A., Puchkov, V. N., Kozlov, V. I., Sergeeva, N. D., and Busharina, S. V.: New data on zircon geochronology of the Arshinian volcanics (Southern Urals), Lithosfera, 4, 127-139, 2012 (in Russian). 
Krasnobaev, A. A., Kozlov, V. I., Puchkov, V. N., Busharina, S. V., Sergeeva N. D., and Paderin I. P.: Zircon Geochronology of Mashak Volcanics and the Age of the Lower-Middle Boundary (Southern Urals), Stratigraphy, Geological correlation, 21, 465481, 2013a.

Krasnobaev, A. A., Puchkov, V. N., Sergeeva, N. D., and Lepekina, E. N.: Zirconology of the Kiryabinka pyroxenite-gabbro complex (Southern Urals), Dokl. Earth Sci., 450, 531-535, 2013b.

Krasnobaev, A. A., Puchkov, V. N., Kozlov, V. I., Sergeeva, N. D., Busharina, S. V., and Lepekhina, E. N.: Zirconology of Navysh Volcanic Rocks of the Ai Suite and the Problem of the Age of the Lower Riphean Boundary in the Southern Urals, Dokl. Earth Sci., 450, 531-535, 2013c.

Krasnobaev, A. A., Valizer, P. M., Anfilogov, V. N., and Busharina, S. V.: Zirconology of Garnet-Glaucophane Schists of the Maksyutov Complex (Southern Urals), Dokl. Earth Sci., 461, 414-418, 2015.

Kulagina, E. I., Nikolaeva, S. V., Gorozhanina, E. N., Kucheva, N. A., Stepanova, T. I., Alekseev, A. S., Richards, B. C., Puchkov, V. N., Kochetova, N. N., Gorozhanin, V. M., Konovalova V. A., Kulagina, E. I., and Nikolaeva, S. V. (Eds): Carboniferous reference sections: potential candidates for the base of the Serpukhovian GSSP and organic buildups, South Urals, A Field Guidebook of XVIII International Congress on the Carboniferous and Permian, Kazan, Russia, 11-15 August 2015, 90 pp., 2015.

Li, H., Lu, S., Su, W., Xiang, Z., Zhou, H., and Zhang, Y.: Recent advances in the study of the Mesoproterozoic geochronology in the North China Craton. Geological Evolution of Asia, J. Asian Earth Sci., 72, 216-227, 2013.

Lu, S., Zhao, G., Wang, H., and Hao, G.: Precambrian metamorphic basement and sedimentary cover of the North China Craton: A review, Precambrian Res., 160, 77-93, 2008.

Maslov, V. A. and Artiyshkova, O. V.: Stratigraphy and correlation of Devonian deposits of the Magnitogorsk megazone of the Southern Urals, Ufa, DizainPoiligraphService, 288 pp., 2010 (in Russian).

Mavrinskaya, T. M. and Yakupov, R. R.: Ordovician deposits of the western slope of the Southern Urals and their correlation based on conodonts and chitinozoans, Russ. Geol. Geophys., 57, 265281, 2016.

Melankholina, E. N.: The comparative analysis of passive margins in the Northern and Central Atlantic, Geotectonics, 4, 80-105, 2011 (in Russian).

Meyer, F. M. and Kisters, A. F. M. (Eds.): The understanding of the orogenic evolution of the Southern Urals, Geologische Rundschau, Int. J. Earth Sci., 87, 497-616, 1999.

Morozov, A. F. (Ed.): The deep structure and geodynamics of the Southern Urals (URSEIS-95 Project), GERS, Tver, 250 pp., 2001 (in Russian).

Nedosekova, I. L.: The age and sources of matter of the IlmenyVishnevye Gory alkaline complex (Urals, Russia): geochemical and isotope $\mathrm{Rb}-\mathrm{Sr}, \mathrm{Sm}-\mathrm{Nd}, \mathrm{U}-\mathrm{Pb}, \mathrm{Lu}-\mathrm{Hf}$ data, Lithosphere, 5, 77-95, 2012 (in Russian).

Paverman, V. I.: Paleomagnetism of the Middle Paleozoic of the South of the Siberan platform: geodynamic conclusions, Canidate of Sciences Thesis, Moscow, 26 pp., 2016 (in Russian).

Pavlenkova, N. I. (Ed.): Structure and dynamics of the lithosphere of the Eastern Europe, The research results under the EUROPROBE Programme, GEOKART, GEOS, 736 pp., 2006.
Pérez-Estaún, A., Brown, D., and Gee, D. G.: EUROPROBE's Uralides Project, Tectonophysics, 276, 335 pp., 1977.

Puchkov, V. N.: Paleogeodynamics of the Southern and Middle Urals, Ufa, Dauria, 146 pp., 2000 (in Russian).

Puchkov, V.: Paleozoic evolution of the East European continental margin involved into the Urals, Mountain Building in the Uralides: Pangea to the Present, AGU Geophys. Monogr. Ser., 132, 9-32, 2002.

Puchkov, V. N.: Plume and plate-tectonic mechanisms: mutual influence, interference, interaction and intertwining, EGS - AGU - EUG Joint Assembly, Nice, France, 6-11 April 2003, 14251, 2003.

Puchkov, V. N.: On the age of the Uralian ophiolites, in: Ophiolites geology, petrology, metallogeny and geodynamics, Ekaterinburg, IGG Ur B RAS, 121-129, 2006.

Puchkov, V. N.: The controversy over plumes: who is actually right?, Geotectonics, 43, 1-17, 2009a.

Puchkov, V. N.: The evolution of the Uralian orogeny, Geological Society, London, Special Publications, 327, 161-195, 2009b.

Puchkov, V. N.: Geology of the Urals and Cis-Urals (actual problems of stratigraphy, tectonics, geodynamics and metallogeny), Ufa, DesignPoligraphService, 280 pp., 2010 (in Russian).

Puchkov, V. N.: Dike swarms and related igneous complexes in the Urals, Geotectonics, 46, 37-46, 2012.

Puchkov, V. N.: Plume events in the Urals, "RODINIA-2013: Supercontinental Cycles and Geodynamics", Moscow, MGU, 59 pp., 2013a.

Puchkov, V. N.: Structural stages and evolution of the Urals, Miner. Petrol., 107, 3-37, 2013b.

Puchkov, V. N.: Plumes in the history of the Urals, Bull. of the Moscow Society of Nature Investigators, Geological section, 4, 64-73, 2013c (in Russian).

Puchkov, V. N.: General features relating to the occurrence of mineral deposits in the Urals: What, where, when and why, Ore Geol. Rev., doi:10.1016/j.oregeorev.2016.01.005, online first, 2016a.

Puchkov, V. N.: Relationship between plume and plate tectonics, Geotectonics, 50, 88-104, 2016b (in Russian).

Puchkov, V. N. and Danukalova, G. A.: The Late Pliocene and Pleistocene history of the Southern Urals region in the light of neotectonic data, Quatern. Int., 201, 4-12, 2009.

Puchkov, V. N. and Svetlakova, A. N.: New data on tectonics of the western slope of the Southern Urals (based on reflection profile no. 4), Doklady Earth Sciences, 444, 676-680, 2012.

Puchkov, V. N, Kashubin, S. N., and Pérez-Estaún, A. (Eds.): URALIDES Project: Structure and evolution of the Urals, in: Structure and dynamics of the lithosphere of the Eastern Europe, The research results under the EUROPROBE Programme, GEOS, 345-490, 2006 (in Russian).

Puchkov, V. N., Krasnobaev, A. A., Schmitz, M., Kozlov, V. I., Davydov, V. I., Lepekhina, E. N., and Nekhorosheva, A. G.: The new $\mathrm{U}-\mathrm{Pb}$ dates for volcanics of the Riphean Mashak Formation of the Southern Urals and their comparative evaluation, Geological Sbornik, Inst. Geol. RAS, 8, 1-14, 2009 (in Russian).

Puchkov, V. N., Kozlov, V. I., and Krasnobaev, A. A.: Paleozoic U-Pb SHRIMP- dates of magmatic rocks of Bashkirian meganticlinorium Geological Sbornik, Inst. Geol. RAS, 9, 36-43, 2011 (in Russian).

Puchkov, V. N., Bogdanova, S. V., Ernst, R., Kozlov, V. I., Krasnobaev, A. A., Soderlund, U., Wingate, W. T. D., Postnikov, A. 
V., and Sergeeva, N. D.: The ca. 1380 Ma Mashak Igneous Event of the Southern Urals, Lithosphere, 174, 109-124, 2013.

Puchkov, V. N., Krasnobayev, A. A., and Sergeeva, N. D.: The New Data on Stratigraphy of the Riphean Stratotype in the Southern Urals, Russia, J. Geosci. Environ. Protect., 2, 108-116, 2014.

Puchkov, V. N., Ernst, R. E., Hamilton, M. A., Söderlund, U., and Sergeeva, N.: A Devonian $>2000-\mathrm{km}$ long dolerite swarm belt and associated basalts along the Urals-Novozemelian foldbelt: part of an East-European (Baltica) LIP tracing the Tuzo Superswell, GFF, 1, 6-16, 2016.

Reichow, M. K., Saunders, A. D., Pringle, M. S., Al'Mukhamedov, A. I. Medvedev, A. Ya., Allen, M. B., Andreichev, V. L., Buslov, M. M., Fedoseev, G. S., Safonova, I. Yu., Davies, C. E., Fitton, J. G., Inger, S., Mitchell, C., Puchkov, V. N., and Scott, R. A.: The timing and extent of the eruption of the Siberian Traps large igneous province: Implications for the end-Permian environmental crisis, Earth Planet. Sci. Lett., 277, 9-20, 2009.

Ronkin, Y. L., Sindern, S., and Lepikhina, O. P.: Isotopic geology of the most ancient formations of the Southern Urals, Lithosphere, 5, 50-76, 2012 (in Russian).

Ryazantsev, A. V.: The Ordovician Complexes of the Western Part of the Magnitogorsk Megazone and Marginal Allochthons of the Southern Urals: Structure and Environments of Origin, Thes. of Candidate Dissertation Geological Institute RAS, Moscow, 32 pp., 2012 (in Russian)

Rybalka, A. V.: Seismological model of the Earth's crust of the Middle Urals (after materials of the Middle Urals transect), Thesis of Candidate of Science dissertation, Ekaterinburg, 24 pp., 2015 (in Russian).

Saveliev, D. E., Snachev, V. I., Savelieva, E. N., and Bazhin, E. A.: Geology, petrogeochemistry and chromite potential of gabbroultramafic massifs of the Southern Urals, Ufa, DizainPoligraphService, 320 pp., 2008.

Savelieva, G. N., Puchkov, V. N., and Spadea, P.: Ophiolites of the Urals, The Structure and Dynamics of Lithosphere of Eastern Europe: The Results of Research under the EUROPROBE Program, GEOS, 421-436, 2006a (in Russian).

Savelieva, G. N., Shishkin, M. A., and Larionov, A. N.: Tectonomagmatic events of the Late Vendian in the mantle complexes of the ophiolits of the Polar Urals; U-Pb dating of zircons of chromites, in: Ophiolites - geology, petrology, metallogeny and geodynamics, Ekaterinburg, IGG Ur B RAS, 160-164, 2006b (in Russian).

Sergeeva, N. D., Puchkov, V. N., Krasnobayev, A. A., and Ratov A. A.: Limitotype of a stratigraphic boundary of the Lower Riphean in the Southern Urals, Geol. Sbornik, Inst. Geol. RAS, 11, 64-70, 2013 (in Russian).
Sindern, C., Ronkin, Yu. L., and Hetzel, R.: Taratash and Aleksandrovka Metamorphic Complexes (Southern (Urals): T-t Restrictions, Inst. of Geology and Geochemistry, Uralian Branch of RAS, 322-330, 2006 (in Russian).

Snachev, A. V., Snachev, V. I., Rykus, M. V., Saveliev, D. V., Bazhin, E. A., and Ardislamov, F. R.: Geology,petrogeochemistry and ore potential of carbonaceous deposits of the Southern Urals/Ufa, DizainPress, 208 pp., 2012.

Svetlakova, A. N., Gorozhanina, E. N., Puchkov, V. N., Gorozhanin, V. M., Karnaukhov, S. M., Poberezhsky, S. M., and Gorelikov, V. I.: The Perovsk-Kornilovka swell: a previously unknown large structural unit of the Orenburg cisural region, Dokl. Earth Sci., 412, 49-52, 2007.

Svetlakova, A. N. Gorozhanina, E. N., Gorozhanin, V. M., Razuvaev, V. I., Puchkov, V. N., Dnistryansky, V. I., Gorelikov, V. I., and Poberezhsky, S. M.: New data on the structure of the southern part of the cis-uralian foredeep according to results of seismic work, Dokl. Earth Sci., 423, 1352-1356, 2008.

Svyazhina, I. A., Puchkov, V. N., Ivanov, K. S., and Petrov, G. A.: Paleomagnetism of the Ordovician of the Urals, Uralian Branch of Russian Academy, Ekaterinburg, 136 pp., 2003 (in Russian).

Valizer, P. M., Krasnobaev, A. A., and Rusin, A. I.: UltrahighPressure (UHP) Associations in Ultramafites of the Maksutov Complex (Southern Urals), Dokl. Earth Sci., 441, 1645-1648, 2011.

Valizer, P. M., Krasnobaev, A. A., and Rusin A. I.: UHPM Eclogite of the Maksyutov Complex (Southern Urals), Dokl. Earth Sci., 461, 291-296, 2015.

Yang, J. S., Zhang, X. X., Xu, X. Z., Zhang, Z. M., Huang, Z., Robinson, P. T., Dilek, Y., and Griffin, W. L.: Diamonds and highly reduced minerals in ophiolitic mantle rocks and chromitites, 12th International Platinum Symposium, Institute of Geology and Geochemistry UB RAS, Yekaterinburg, 328-329, 2014

Youbi, N., Kouyaté, D., Söderlund, U., Ernst, R. E., Soulamani, A., Hafid, A., Ikenne, M., El Bahat, A., Bertrand, E., Chaham, K. R., Ben Abbou, M., Mortaji, A., Tl Ghorfi, M., Zouhair, M., and El Janati, M.: The 1750 Ma Magmatic Event of the West African Craton (Anti-Atlas, Morocco), Precambrian Res., 238, 106-123, 2013.

Znamenskii, S. E., Svetlakova, A. N., and Puchkov V. N.: The structural peculiarities of the Dzhetygara-Troitsk zone, Southern Urals (based on the URSEIS-95 profile), Dokl. Earth Sci., 448, 31-33, 2013.

Zonenshain, L. P., Kuzmin, M. I., and Natapov, L. M.: Geology of the USSR, a plate tectonic synthesis - American Geophysical Union, Geodynamic Series, 21, 242 pp., 1990. 